\title{
Evaluation of mass bathing effects on water quality status of eight prominent ponds of Haryana (India): A multi-location study
}

\author{
Pooja Devi \\ Government P.G. College, Ambala Cantt. (Haryana), India \\ Anita Bhatnagar* \\ Department of Zoology, Kurukshetra University, Kurukshetra, Haryana-136119, India \\ Mohan P. George \\ Delhi Pollution Control Committee, ISBT Building, Delhi, India \\ ${ }^{*}$ Corresponding author. E-mail: anitabhatnagar@gmail.com
}

\begin{abstract}
Amongst the various anthropogenic activities, mass bathing and other religious rituals also affect the water quality of aquatic ecosystem. The present research has been conducted to evaluate the impact of mass bathing and other religious activities on the eight famous religious water bodies of Haryana (Kapalmochan tirth, Kulotarn tirth, Ban-Ganga tirth, Brahmsarovar, Jyotisar, Saraswati tirth, Phalgu tirth and Pandu-Pindara tirth). The water samples were collected from three sampling stations (A, B and $C)$ at each of the eight selected sites ( $\mathrm{S} 1$ to $\mathrm{S} 8$ ) before and after the religious rituals and also seasonally. The samples were analyzed for Dissolved oxygen (DO), Biochemical Oxygen Demand (BOD), Chemical Oxygen Demand (COD) ammonia and heavy metals . The study highlighted the seasonal variations of physicochemical characteristics and also the effects of mass bathing and religious activities on water quality of the religious sites. Although the water was reported as safe in terms of DO content, total ammonia, BOD and the values of $C O D$ before the religious rituals but the values exceeded the maximum permissible limit $\{\mathrm{DO}(0.8 \pm 0.1,0.76 \pm 0.11)$, BOD $(25.07 \pm 0.13,18.13 \pm 0.13)$, COD (131.9 \pm 2.08$)$, Ammonia $(2.31 \pm .23,6.57 \pm 0.02)$ Iron $\left(5890 \mu \mathrm{g} \mathrm{L}^{-1}\right)$ and Zinc $\left.\left(200 \mu \mathrm{g} \mathrm{L}^{-1}\right)\right\}$ after mass bathing and religious rituals indicating that the water was not suitable for drinking as well as bathing purposes after the rituals/mass bathing. So, bathing during/after such rituals may become a health hazards to the bathers or users of the water and also may affect the aquatic biota, further depleting it. There is thus a need of regular monitoring and regular application of suitable remedial measures to prevent the depletion of the quality of lentic waters.
\end{abstract}

Keywords: BOD, COD, DO, Mass bathing, Religious activity, Water quality

\section{Article Info}

DOI:10.31018/jans.v11i2.2044 Received: March 20, 2019 Revised: May 5, 2019

Accepted: May 13, 2019

\section{How to Cite}

Devi, P. et al. (2019). Evaluation of mass bathing effects on water quality status of eight prominent ponds of Haryana (India): A multi-location study. Journal of Applied and Natural Science, 11(2): 361-371 https://doi.org /10.31018/jans.v11i2.2044

\section{INTRODUCTION}

Every lake and river is subjected to more than one organized use such as irrigation, industry, agriculture, navigation, boating, cooking, drinking, power generation, sewage discharges, and groundwater leaching, runoff, fisheries and bathing etc. (Kaul and Pandit, 2004; Bhatnagar et al., 2009; Sundararajan and Anand, 2011; Appavu et al., 2016). These anthropogenic practices are creating a pressure on world's water resources and thereby deteriorating the water quality to a greater extent (Rangarajan et al., 2006; Singh et al., 2007; Neamtu et al., 2009; Bhatnagar and Singh, 2010a,b; Kuwabara et al., 2013; Singh et al., 2016; Sharma and Giri, 2018). Among these, mass bathing and religious activities is also one of the major causes responsible for altering or declining of water quality. Many rituals are associated with religious activity like idol immersions containing col- oured pigments and paints having harmful chemicals, Pind Daan, Deep Daan (Enlightened Diyas having oils in them), bathing, washing, immersion of clothes, ash, oil, flour, floral offerings, coconut shells, plastic, wood, detergents, soap and other domestic wastes in the water bodies; which increases the pollution load in the water body and deteriorates the quality of waters (Bhatnagar and Sangwan, 2009; Gupta et al., 2011 and Singh and Nath, 2015). This is the time when the already overburdened religious tanks/ ponds are subjected to an even greater load and this consequential deterioration of water quality leads to a condition where such water becomes unsuitable in terms of its uses like recreation, bathing and a source of raw water supply (Biswas, 2000; Khan et al., 2004). The deteriorating quality of the water is threatening the sustainability of water resources and is therefore a cause for concern. Some pilgrims carry infections of skin and other 
diseases, so there is a risk of spread of water borne diseases like cholera, typhoid, dysentery, rashes, leptospirosis and more that affect human health. Many of these diseases have become widespread and account for $2 / 3$ of illness in India (Munawar, 1970). Maximally children of developing countries become victim of death every year due to the water related diseases (WHO, 1993).Mass bathing and other religious immersion activities also lead to the addition of chemical colour, varnish, paints, sindur, coins and oils etc. into the aquatic systems indirectly acting as a source of different heavy metals in the waters. Lead and Chromium which are very toxic even in very low concentration, usually being added through "Sindur" in the water bodies (Bubicz, 1982). Bioaccumulation of these toxic metals in higher trophic levels within a food web bring about harmful effects on biochemical life process of the aquatic organisms (Tay et al., 2009) and also threat to human health upon consumption as these tend to get biomagnified. Haryana is a state where religious activities are intensely associated with its cultural heritage and there are several ponds which are considered to be sacred by Hindus and where such religious activities and mass bathing are performed in routine manner during Solar eclipse, Amavasya (New Moon Day), Shradh period (Sept. /Oct.), Purnima (Full Moon Day on Kartik month / Nov).

So, thinking about the recent realization of pollution hazards, it becomes necessary to conduct research on water quality assessment studies. Unfortunately, a very limited work has been done in order to assess the quality of lentic religious water bodies of Haryana. Keeping the above scenario in mind, mass bathing and religious rituals effect on quality of eight religious water bodies of Haryana was assessed in term of few pollution indicating parameters viz., DO, BOD, COD, Ammonia and heavy metals before and after days of religious rituals or mass bathing.

\section{MATERIALS AND METHODS}

Description of study area: The present study is concerned with the holy tanks of Haryana State (India) famous for mass bathing and various types of religious activities taking place there. These are S1 (Village- Bilaspur, Yamunanagar), S2 (VillageKirmach, Kurukshetra), S3 (Village- Dayalpur, Kurukshetra), S4 (Kurukshetra), S5 (Kurukshetra), S6 (Pehowa, Kurukshetra), S7 (Village- Pharal, Kaithal) and S8 (Village- Pandu-Pindara, Jind). The study area and the details of all the religious activities taking place at each site have been shown in table 1.

Location of sampling stations: Keeping in view the number of pilgrims taking dip in pilgrimage spots, three sampling stations i.e. A, B and C were chosen for studying the water quality of each selected site. A site was selected where minimum number of people used to take bath; B was selected where maximum number of people used to take bath and $\mathrm{C}$ was selected where also large number of people take bath but comparatively less than B (i.e. intermediate numbers of pilgrims were recorded here).

\section{Experimental protocol}

Limnochemical characteristics: Surface water samples were collected from February 2012 to February 2013, from three selected stations, in triplicate; two days before and one day after the religious ritual and also seasonally from all the selected eight sites. The religious activities occurred two times at S3, S4, S5, S6 and S8 and only once at sites $\mathrm{S} 1, \mathrm{~S} 2$ and $\mathrm{S} 7$ during the study period and seasonally as well. The samples could not be collected during winter at S2 due to occurrence of construction process in winter season (Table 2). The physico-chemical characteristics viz. Dissolved oxygen, Biochemical Oxygen Demand, Chemical Oxygen Demand and Ammonia were analyzed in laboratory according to standard procedures (APHA, 2005).

Heavy metal analysis: For the heavy metal analysis, water sample was preserved in refrigerator, after acidification with $\mathrm{HNO}_{3}$ to $\mathrm{pH}$ 2.0; Zinc (Zn), Copper (Cu), Cadmium (Cd), Nickel (Ni) and Lead $(\mathrm{Pb})$ were analyzed on ICP-OES-710 Varian instrument in Sophisticated Industrial Material AnaIytic Lab, Mayapuri Industrial area, New Delhi.

Statistical analysis: Coefficient of correlation between different independent and dependent parameters was calculated according to SPSS 11.5 packages. Significant differences before and after religious activity were calculated by student's ' $\mathrm{t}$ ' test following Snedecor and Cochran (1967) and the mean values of all the parameters at all the sites were compared by using Duncan Multiple Range Test (1975).

\section{RESULTS}

DO: In the present investigation, DO ranged from 6.14 to $14.14 \mathrm{mg} \mathrm{L}^{-1}$ before dip and 0.76 to 11.96 $\mathrm{mg} \mathrm{L}^{-1}$ after the mass bathing or religious activity. The graphical representation of dissolved oxygen variations depicted a general and significant $(p<$ 0.05 ) decline in the values of $D O$ after the pilgrim dip at all the sites with least value of DO at S8 Pindara (after the Shradh period, during which mass bathing is done). However, maximum per cent decrease was noticed at S2 and S8 after the religious rituals (Fig. 1 and 2). Overall higher values of DO were reported during post monsoon season and lower values were reported during the winter season. It was reported maximum at $\mathrm{S7}$ during post monsoon season (Table 2).

BOD: It gives an indication of quantity of biodegradable organic substances present in water, subjected to aerobic decomposition of microor- 


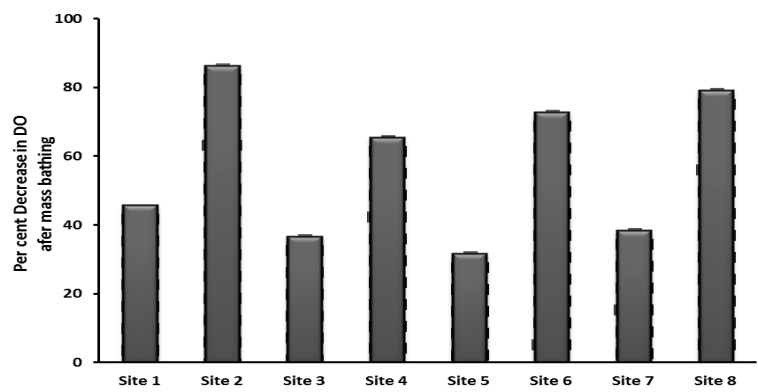

Fig. 1. Per cent decrease in the DO at all the selected sites after the mass bathing in comparison to initial values.

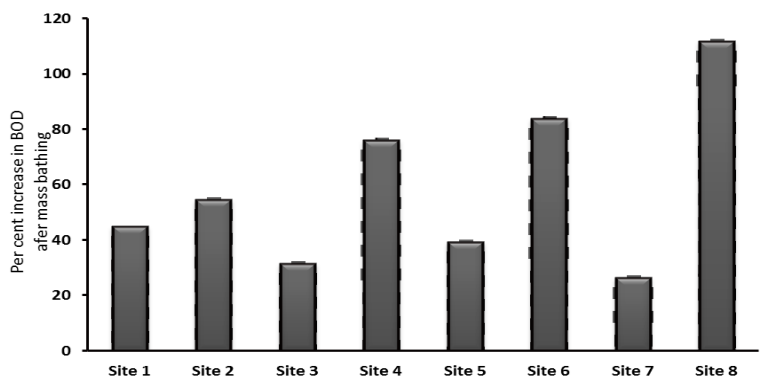

Fig. 2. Per cent increase in the $B O D$ at all the selected sites after the mass bathing in comparison to initial values.

ganisms. Thus, it provides a direct measurement of state of pollution. BOD varied from 5.07 to $13.73 \mathrm{mg} \mathrm{L}^{-1}$ before mass bathing and 8.27 to $25.07 \mathrm{mg} \mathrm{L}^{-1}$ after the mass bathing. The graphical representation of BOD variations showed a significant per cent increase in BOD values after the dip at all the selected sites and maximum per cent increase in BOD after mass bathing was observed at S8 followed by the value at S6 (Fig. 2). The highest value of BOD was observed at S6 after the religious rituals of Shradh period in October 2013. Highest value of BOD was reported at S7 during monsoon season (Table 2).

COD: It indicates the amount of oxygen necessary for the oxidation of organic and inorganic content of given sample of waters. During the present investigation COD varied from 123.33 to $347.62 \mathrm{mg} \mathrm{L}^{-1}$ before mass bathing and 284.29 to $407.14 \mathrm{mg} \mathrm{L}^{-1}$ after mass bathing. The graphical

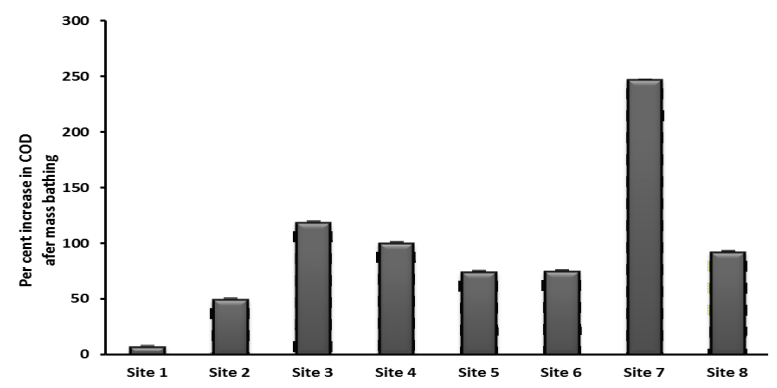

Fig. 3. Per cent increase in the $C O D$ at all the selected sites after the mass bathing in comparison to initial values.

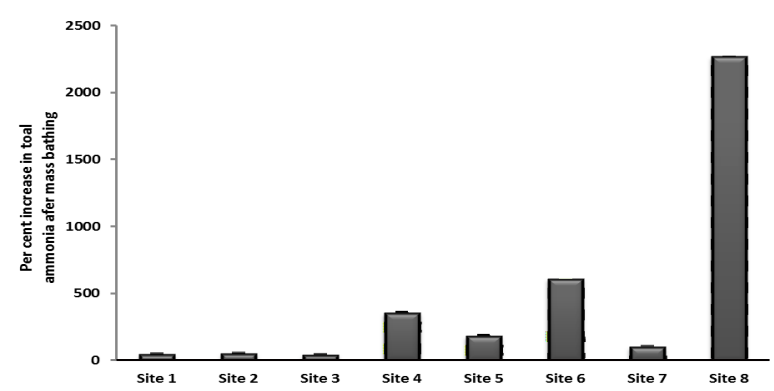

Fig. 4. Per cent increase in the Ammonia at all the selected sites after the mass bathing in comparison to initial values.

representation of COD variations revealed (Fig. 3) a significant per cent increase in COD values after the dip and it was highest at S7. Seasonally higher values of COD were observed during monsoon season followed by value during summer season at most of the sites and lower values were reported during winter season (Table 2).

Ammonia: In the present investigation the ammonia ranged from 0.07 to $0.9 \mathrm{mg} \mathrm{L}^{-1}$ before dip and 0.25 to $28.68 \mathrm{mg} \mathrm{L}^{-1}$ after dip. The maximum concentration of ammonia was found at S8- Pindara after solar eclipse mass bath. A significant per cent increase in the values of ammonia after the pilgrim dip was observed at all the sites however it was maximum at S8 followed by at S6 (Fig. 4). Higher increase of ammonia was noticed at S8- Pindara after the solar eclipse mass bath indicating high pollution status of the tank after the religious rituals of the pilgrims (Table 2). Season wise analysis

Table 1. Details of various selected sites and the related religious activities taking place there.

\begin{tabular}{|c|c|c|c|c|}
\hline S.N. & Sites & District & Latitude, Longitude & Religious activities \\
\hline 1. & S1 & Yamunanagar & $30^{\circ} 326^{\prime} \mathrm{N}, 77^{0} 317^{\prime} \mathrm{E}$ & $\begin{array}{l}\text { Purnima ( Kartik / Nov) Gurunanakjayanti (Mass } \\
\text { bathing) }\end{array}$ \\
\hline 2. & S2 & Kurukshetra & $29^{0} 961^{\prime} \mathrm{N}, 76^{\circ} 827^{\prime} \mathrm{E}$ & Amavasya, Solar eclipse (Mass bathing) \\
\hline 3. & S3 & Kurukshetra & $29^{0} 956^{\prime} \mathrm{N}, 76^{0} 778^{\prime} \mathrm{E}$ & Amavasya, Solar eclipse (Mass bathing) \\
\hline 4. & S4 & Kurukshetra & $29^{0} 937^{\prime} \mathrm{N}, 76^{0} 813^{\prime} \mathrm{E}$ & Vaishakhi (April) (Mass bathing) \\
\hline 5. & S5 & Kurukshetra & $29^{0} 922^{\prime} N, 76^{0} 806^{\prime} \mathrm{E}$ & Fair at September month (Mass bathing) \\
\hline 6. & S6 & $\begin{array}{l}\text { Pehowa, Ku- } \\
\text { rukshetra }\end{array}$ & $29^{0} 978^{\prime} \mathrm{N}, 76^{0} 596^{\prime} \mathrm{E}$ & $\begin{array}{l}\text { Pind-dan and bathing during Sharad, Solar eclipse } \\
\text { and Kartik amavasya }\end{array}$ \\
\hline 7. & S7 & Kaithal & $29^{0} 835^{\prime} \mathrm{N}, 76^{0} 587^{\prime} \mathrm{E}$ & $\begin{array}{l}\text { Pind-dan and bathing during Somvati amavasya of } \\
\text { Shradh (Sept-Oct) }\end{array}$ \\
\hline 8. & S8 & Jind & $29^{0} 309^{\prime} \mathrm{N}, 76^{0} 322^{\prime} \mathrm{E}$ & $\begin{array}{l}\text { Pind-dan and bathing during Somvati amavasya, } \\
\text { Solar eclipse, Sharadh }\end{array}$ \\
\hline
\end{tabular}


Devi, P. et al. / J. Appl. \& Nat. Sci. 11(2): 361- 371 (2019)

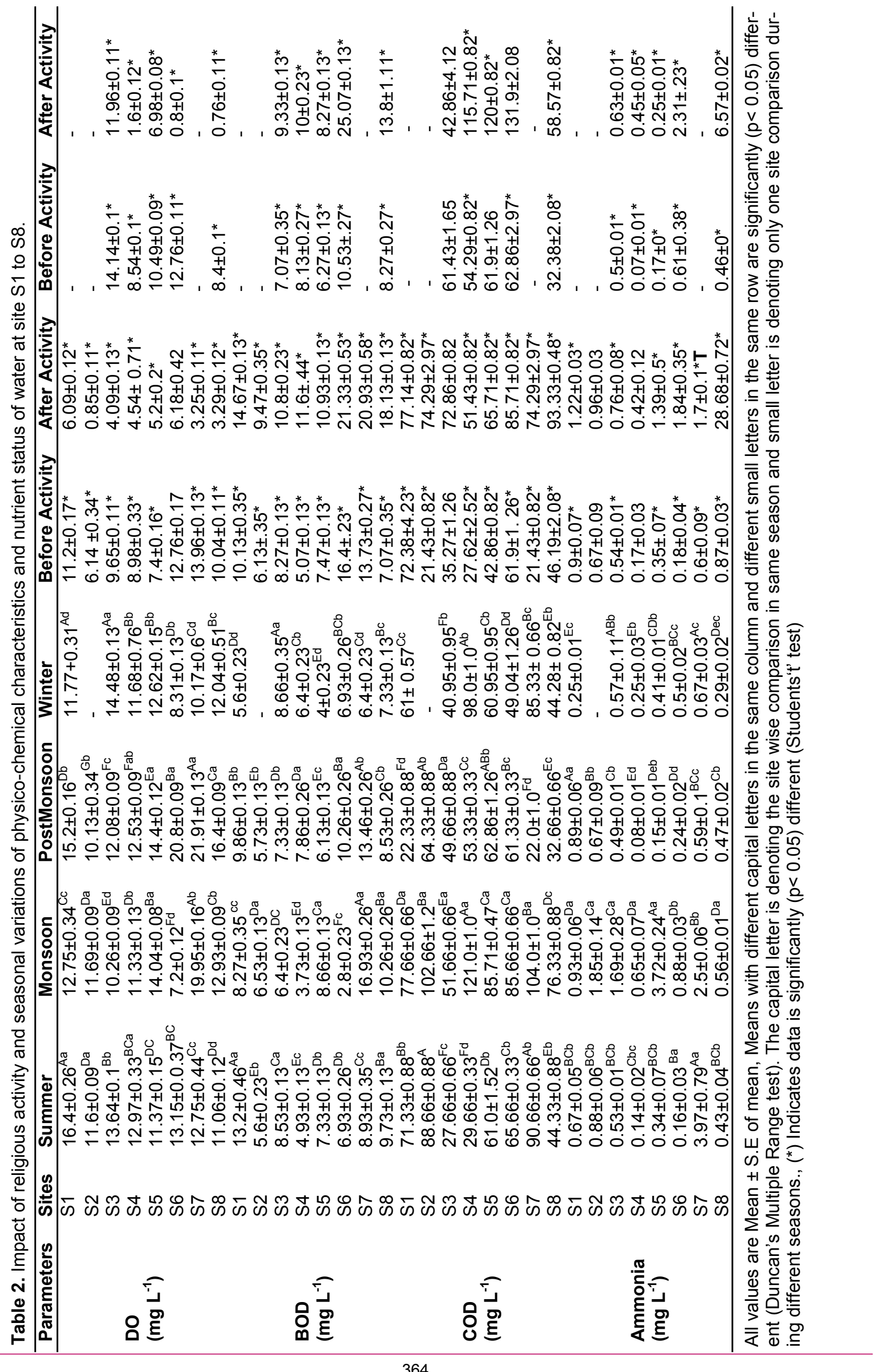




\section{Devi, P. et al. / J. Appl. \& Nat. Sci. 11(2): 361- 371 (2019)}

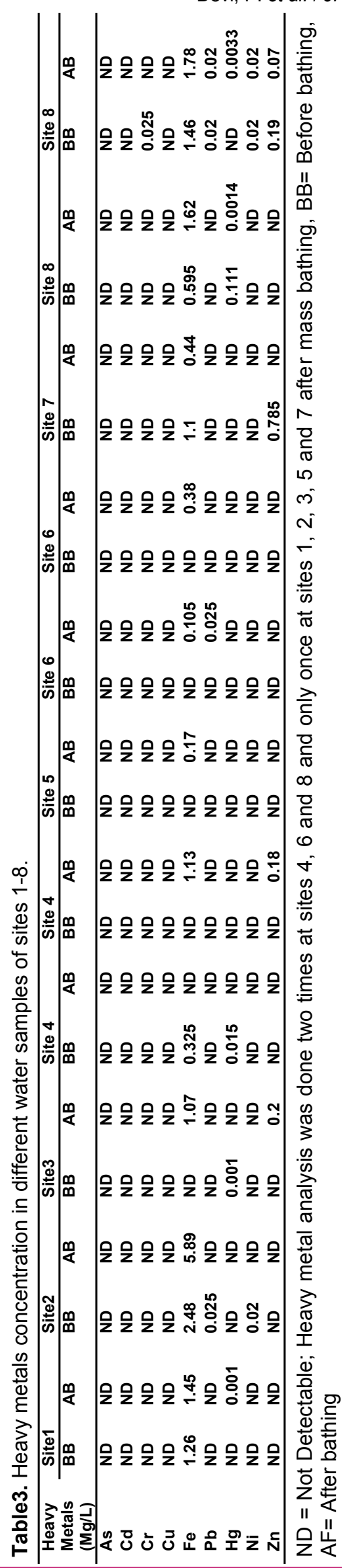

depicted overall higher values of ammonia during monsoon season at most of the selected sites and it was higher at S5. However, higher values of ammonia were also recorded at S7 during summer season (Table 2).

Heavy metal analysis: Heavy metals are regarded as serious pollutants in the aquatic environment because of their environmental persistence and tendency to concentrate in aquatic organisms. At S2 concentration of $\mathrm{Fe}$ (5.89 ppm) was found to be the highest after the religious activity whereas concentration of As, Cd was recorded nil at all the sites. Concentration of $\mathrm{Cr}(0.025 \mathrm{ppm})$ and $\mathrm{Cu}$ (0.03 ppm) was recorded only at S7 and S5 respectively. Table 3 shows an increase in concentration of $\mathrm{Fe}$ almost at all the sites while concentration of $\mathrm{Pb}, \mathrm{Hg}$ and $\mathrm{Zn}$ was also found to be increased after the religious activity at several sites whereas $\mathrm{Cr}, \mathrm{Cu}$, and $\mathrm{Ni}$ did not show any specific trend. The trend in the concentration of different heavy metals recorded at sites $S 1$ to $S 8$ was $\mathrm{Zn}>\mathrm{Fe}>\mathrm{Hg}>\mathrm{Cu}>\mathrm{Cr} \geq \mathrm{Pb}>\mathrm{Ni}>\mathrm{As} \geq \mathrm{Cd}$ (Table 3).

\section{DISCUSSION}

The level of DO content in any aquatic system may be used as an index of water quality for the study of pollution (Thirumala et al., 2011) and can also be considered one of the very essential parameter that can determine the ecological status of an aquatic system protecting the aquatic life (Chang, 2002). DO more than $5.0 \mathrm{mg} \mathrm{L}^{-1}$ is a good indication of a highly productive nature of water body (Das, 2000). In the present findings all the sites were having DO values more than $5 \mathrm{mg} \mathrm{L}^{-1}$ indicating the productive nature of all the sites. According to Chaturvedi et al. (2003), DO content of good water should be between 7.6 and $7.0 \mathrm{mg}$ $\mathrm{L}^{-1}$ at 30 and $35{ }^{\circ} \mathrm{C}$ respectively. In this research, DO fluctuated from 6.14 to $14.14 \mathrm{mg} \mathrm{L}^{-1}$ before dip and 0.76 to $11.96 \mathrm{mg} \mathrm{L}^{-1}$ after the mass bathing or religious activity. The higher amount of dissolved oxygen i.e. more than $10 \mathrm{mg} \mathrm{L}^{-1}$ at some sites may be due to the presence of excess algal blooms and their increased photosynthetic activity during the day period, further solubility of the gas also affected by salinity and altitude as it increases with decreasing salinity and decreases as pressure decreases. A significant $(p<0.05)$ decrease in the DO has been noticed in the present investigations after the mass bathing (Fig. 1) and it was higher at sites S2, S6 and S8, which agrees with the findings of Rao and Rao, 1986 (Kumbh Mela in Kshipra River, Ujjain), Kulshreshtha et al., 1988 (Upper lake Bhopal), Sinha et al., 1991 (Ganga River at Haudeshwarnath, Pratapgarh) Lal, 1996 (Pushkar Sarovar), Kulshreshtha and Sharma, 2006 (Ganga river during Ardhkumbh), Vyas and Bajpai, 2008 (Idol immersion in context of lower Lake Bhopal India) and Bhasin et al., 2015 
(Kshipra river at Triveni, Ujjain, M.P.). Decrease in DO values after bathing may be due to dumping of organic, biodegradable wastes (Dhar et al., 2004 and Winter et al., 2007) and contamination of water with human activities like adding soap and detergents, bathing etc. and absorption of these pollutants by aquatic flora. Due to these activities faecal coliform may also rise and these utilize oxygen for their respiration and hence may lead to depletion of DO.

Overall higher values of DO were reported during post monsoon (Table 2). Relatively higher oxygen concentrations in winter and post-monsoon season were observed by Sadhuram et al. (2005) and George et al. (2012) because of maximum occurrence of the phytoplankton density (Morgan et al., 2006). The moderate temperature and photosynthetic activity of the phytoplankton and microphytes during post monsoon season could be the reason for higher DO values (Bohra, 1990). However, higher level of dissolved oxygen during autumn and winter seasons with an average DO content as $4.2 \pm 0.30 \mathrm{mg} \mathrm{L}^{-1}$ was assessed by Ahangar et al. (2012) in Anchar lake, Kashmir. Baskar et al. (2013) reported minimum level of dissolved oxygen during summer and maximum during monsoon periods while studying seasonal variations of Cauveri river, Thanjavur, Tamil Nadu. Similar observation was also made by Abida and Harikrishna (2008) and Singh et al. (2010). In all seasons the level of DO was found within the permissible limits of the water quality guidelines as (Table 4) the water was suitable for bathing or swimming purpose and was suitable for aquatic flora and fauna when there is no ritual activity. However, at sites S2, S4, S6, S7 and S8 the level of DO was found below the water quality guidelines for mass bathing suggesting the water was not suitable for bathing or swimming after the religious rituals. An inverse relationship of DO with BOD $(r=-0.54, p<0.01)$ in present findings revealed dissolved oxygen decreases with increase in BOD.

$B O D$ is found to be more sensitive test for organic pollution. A significant per cent $(p<0.05)$ increase in BOD values was reported (Fig. 2) after the religious activity and it was highest at $\mathrm{S} 8$ followed by at S6. These results are in accordance with findings of Kulshreshtha and Sharma (2006) who had studied the impact of mass bathing during Ardhkumbh on water quality status of river Ganga. Rao and Rao (1986), Dhote et al. (2001), Vyas et al. (2006), Gupta and Devi (2014) and Bhasin et al. (2015) also found increase in BOD after the mass bathing. Buijs and Toader (2007) suggested maximum permissible limit of BOD for bathing purpose as $6 \mathrm{mg} \mathrm{L}^{-1}$ and it was noticed that all the sites were having more BOD value than the above prescribed value after the pilgrim dip in the present studies (Table 2). This indicated that the water become unsuitable for bathing after the dip. According to Hostetti et al. (1994) the high BOD values between $23.0-56.4 \mathrm{mg} \mathrm{L}^{-1}$ was an indication of high organic pollution load on river. However, in present studies mean values of BOD was recorded lower than the above prescribed limit by Hostetti et al. (1994) at all the sites indicating less organic pollution there before religious rituals (Table 2).

Highest value of BOD was reported at S7 during monsoon season (Table 2) similar to the findings of Essien-lbok et al. (2010) and Rameshbabu and Selvanayagam, (2013) may be attributed to the more addition of decomposable organic matter into the waters via surface run off in rainy season. The BOD is inversely correlated $((r=-0.54, p<$ $0.01)$ with $D O$ suggesting its consumption during aerobic degradation of organic wastes. This is in agreement with the Chandrashekar et al. (2003).

COD can be considered as an important tool for analyzing water quality via measuring the amounts of organic matter present in waters. An indirectly assessment of lethality and persistence of biologically resistant organic compounds can also be done via analyzing the value of COD as well as BOD. Such studies were also conducted by Rajkumar et al. (2003). During the present investigation COD varied from 123.33 to $347.62 \mathrm{mg}$ $\mathrm{L}^{-1}$ before mass bathing and 284.29 to $407.14 \mathrm{mg}$ $\mathrm{L}^{-1}$ after mass bathing. COD variations before and after religious activity (Fig. 3 and Table 2) showed a significant increase in COD values after the mass pilgrim dip and it was highest at S7 after the Shradh period. All the sites were having more values of COD than the prescribed limit for bathing or swimming (Table 4) making a question mark on the suitability of water quality for mass bathing. The increase in COD after mass bathing is in accordance with that of Dhote et al., 2001 (Impact of idol immersion on water quality of twin lakes of Bhopal), Vyas et al., 2006 (impact of idol immersion activity on lakes of Bhopal), Gupta and Devi, 2014 (Baskandianua, an oxbow lake of South Assam), Watkar and Barbate, 2014 (Impact of idol immersion on water quality of Kolar River in Saoner, Dist. Nagpur) and Bhasin et al., 2015 (Impact of mass bathing on water quality of river Kshipra at Triveni, Ujjain, M.P). Seasonally higher values of COD were reported during monsoon season followed by during summer season at most of the sites may be due to high inflow of organic matter during monsoon season. Higher values of COD were also reported by Mathur et al., 1991(Chambal over the stretch of National Chambal sanctuary in M.P.) and Pawale, 2014 (Vishnupuri Reservoir district, Nanded) may be due to high rate of decomposition under high temperature and high evaporation rate during summers. However, lower values of COD observed during winter season at most of the selected sites 
Table 4. Summary of Water quality guidelines for mass bathing/recreation.

\begin{tabular}{|c|c|c|}
\hline S. $\mathbf{N}$. & Parameter & MAC Values (Maximum allowable concenteration) \\
\hline 1 & $\mathrm{DO}\left(\mathrm{Mg} \mathrm{L}^{-1}\right)$ & $\geq 5$ (Tyagi et al., 2013), CPCB (2017), $>4$ (Buijs and Toader, 2007), \\
\hline 2 & $\mathrm{BOD}\left(\mathrm{Mg} \mathrm{L}^{-1}\right)$ & $\leq 3$ (Tyagi et al., 2013), CPCB (2017), 6 (Buijs and Toader, 2007), \\
\hline 3 & $\operatorname{COD}\left(\mathrm{Mg} \mathrm{L}^{-1}\right)$ & 15 (Buijs and Toader, 2007), < 10 CPCB (2017) \\
\hline 4 & Ammonia $\left(\mathrm{Mg} \mathrm{L}^{-1}\right)$ & 0.8 (Buijs and Toader, 2007) \\
\hline 5 & As $\left(\mu \mathrm{g} \mathrm{L}^{-1}\right)$ & $<50$ (EPA, 2018) \\
\hline 6 & $\mathrm{Cd}\left(\mu \mathrm{g} \mathrm{L}^{-1}\right)$ & $<8.8$ (EPA, 2018) \\
\hline 7 & $\operatorname{Cr}\left(\mu \mathrm{g} \mathrm{L}^{-1}\right)$ & $<11$ (EPA, 2018) \\
\hline 8 & $\mathrm{Cu}\left(\mu \mathrm{g} \mathrm{L}^{-1}\right)$ & $\leq 3.7($ EPA, 2018) \\
\hline 9 & $\mathrm{Fe}\left(\mu \mathrm{g} \mathrm{L}^{-1}\right)$ & $<300$ (EPA, 2018) \\
\hline 10 & $\mathrm{~Pb}\left(\mu \mathrm{g} \mathrm{L}^{-1}\right)$ & $\leq 8.5($ EPA, 2018) \\
\hline 11 & $\mathrm{Hg}\left(\mu \mathrm{g} \mathrm{L}^{-1}\right)$ & $\leq 0.012($ EPA, 2018) \\
\hline 12 & $\mathrm{Ni}\left(\mu \mathrm{g} \mathrm{L}^{-1}\right)$ & $<8.3$ (EPA, 2018) \\
\hline 13 & $\mathrm{Zn}\left(\mu \mathrm{g} \mathrm{L}^{-1}\right)$ & $<86$ (EPA, 2018) \\
\hline
\end{tabular}

similar to the findings of Pawale (2014) may be due to low temperature and evaporation rate (Table 2).

Ammonia is a parameter that may induce its toxic effect to fish, aquatic animals as well as on planktons when present even in very small quantity in waters. The values of ammonia more than $0.1 \mathrm{mg}$ $\mathrm{L}^{-1}$ generally indicates the polluted nature of the waters (National Academy of sciences, 1972; Chapman and Kimstach, 1996) The toxicity of ammonia for fish may be determined by temperature, $\mathrm{pH}, \mathrm{DO}$ and also $\mathrm{CO}_{2}$ contents of any aquatic system. The ammonia will be more toxic to the fish at higher temperature and higher $\mathrm{pH}$ and can be said even much more toxic when water contains less amount of $\mathrm{DO}$ and $\mathrm{CO}_{2}$. In the present research mean values of ammonia were found higher than $0.1 \mathrm{mg} \mathrm{L}^{-1}$ at all the sites indicating the polluted status of the sites that need further attention for the improvement of the water quality. A significant $(p<0.05)$ per cent increase in the ammonia was noted after the pilgrim dip (Fig. 4). Dumping of domestic and organic waste and the activities like bathing, adding ashes may be responsible for this increased ammonia concentration. Urination by pilgrims during mass bathing might be one of the important reasons of increase in $\mathrm{NH}_{3}{ }^{-} \mathrm{N}$ after pilgrim dip. However, higher increase was noticed at S8- Pindara after the solar eclipse mass bath indicating high pollution status of the tank after the religious rituals performed by the large number of pilgrims in short area used for mass bathing as compared to other sites (Fig.4). Sites S1, S2, S6, S7 and S8 were reported to have higher values of ammonia as compared to the water quality guidelines for mass bathing or swimming indicating the water was not suitable for bathing purpose after the religious rituals (Table 2).

Season wise analysis showed higher level of ammonia during monsoon and in summers whereas lower level was observed during the post monsoon and winter season. High evaporation rate might be the reason for the comparative increased level of ammonia in summers. According to Abdo
(2005) denitrification process by the reduction of $\mathrm{NO}_{2}^{-}$and $\mathrm{NO}_{3}^{-}$into $\mathrm{NH}_{3}$ may be one of the reasons for increased level of ammonia attributed to the fact that aquatic autotrophs rapidly utilize the ammonium ions, preferring these to nitrates. The results are further supported by the positive relationship of ammonia with temperature $(r=0.410$, $p<0.05)$. The present results are similar to findings of Diaz et al. (1998) for Lake Lasalade de Chiprana (Spain); Morales et al., (2001) for Lake Maracaibo (Venezuela) and Ali, (2002) for Lake Qarun. The presence of lower level of ammonia during winters may be due to oxidation of the ammonia by oxygen rich conditions not because of the uptake of ammonia by the phytoplankton cells (Shabana, 1999). Higher values of ammonia during monsoon season might be due to increase inflow of the load of domestic sewage via surface runoff during the rainy season (Imnatoshi and Sharif, 2012) whereas; Ahangar et al. (2012) observed the higher and lower level of ammonia during winter and summer season respectively during his study on Anchar lake, Kashmir.

$B O D, C O D$ and ammonia revealed significant $(p<$ 0.05 ) increase while DO revealed significant decrease after the pilgrim dip at most of the sites. Decrease in DO concentration and increase in BOD after bathing may be due to dumping of biodegradable waste (ashes, floral offerings, flour etc.) and contamination of water with human activities like addition of soaps, detergents etc. and their absorbance by aquatic flora. A significant ( $p<$ 0.05 ) positive correlation was observed among various pollution indicating parameters such as BOD, COD and ammonia. However, an inverse relationship was observed between DO and BOD.

Heavy metal analysis: Metals in deposition are consequent from both natural and anthropogenic (point and non-point) sources (Baker et al., 1997). Bioaccumulation of the metals in many fish species and their organs have been described worldwide by Kumada et al., 1980; Osborne et al., 1981; Norris and Lake, 1984 and Evans, 1987). In present study, the concentration of different heavy 
metals at sites $\mathrm{S} 1$ to $\mathrm{S} 8$ was found as $\mathrm{Zn}>\mathrm{Fe}>$ $\mathrm{Hg}>\mathrm{Cu}>\mathrm{Cr} \geq \mathrm{Pb}>\mathrm{Ni}>\mathrm{As} \geq \mathrm{Cd}$ (Table 3). Lead and cadmium is also reported by Yigit and Altindag (2006), but they reported $\mathrm{Cd}>\mathrm{Pb}$. The heavy metals $\mathrm{Cu}, \mathrm{Zn}$ were detected also by Baptiste and Altaff (2003) in freshwater cultural ponds of Palvakkam, Chennai. Zinc is an essential element in soil as an organic complexes and inorganic salts. Zinc sulphates containing fertilizers are also responsible for higher values of $\mathrm{Zn}$ in water $\mathrm{Wu}$ et al. 2008). In the present study $\mathrm{Zn}$ ranged from $70 \mu \mathrm{g} \mathrm{L}^{-1}$ to $785 \mu \mathrm{g} \mathrm{L}^{-1}$ in contrary to the findings of Al-Badaii and Shuhaimi-Othman (2014) that reported the $\mathrm{Zn}$ range from 33.10-49.19 $\mathrm{\mu g} / \mathrm{L}$ in Semenyih River, Peninsular Malaysia and Varunprasath and Daniel (2010) observed the range of 40-60 $\mathrm{g} \mathrm{L} \mathrm{L}^{-1}$ in Bhavani river, Tamilnadu. Highest value of $\mathrm{Zn}$ was examined at S6 during post monsoon period. Increase in the values of $\mathrm{Zn}$ was noticed at S3 from 0 to $180 \mathrm{\mu g} \mathrm{L}^{-1}$ and at S4 from 0 to $200 \mu \mathrm{g} \mathrm{L}^{-1}$ after the religious activity and it was found to be higher than the prescribed limit i.e. $86 \mu \mathrm{L} \mathrm{L}^{-1}$ of bathing standards (Table 4). Bathing and washing activities by pilgrims with detergents, soaps and shampoos may be the possible cause of increase in $\mathrm{Zn}$ level after the religious activity may be supported by the findings of Aonghusa and Gray (2002) who found laundry detergents as a source of $\mathrm{Zn}$ in Irish water. Iron is one of the most abundant metals found on the earth crust and is essential for aquatic life and human beings. The $\mathrm{Fe}$ concentration of water samples ranged from $70 \mu \mathrm{g} \mathrm{L}^{-1}$ to $589 \mu \mathrm{g} \mathrm{L}^{-1}$. Considerable increase in the concentration of $\mathrm{Fe}$ was recorded at sites S1 (1260 to $\left.1450 \mu \mathrm{g} \mathrm{L}^{-1}\right), \mathrm{S} 2$ (2480 to 5890 $\left.\mu \mathrm{g} \mathrm{L}^{-1}\right), \mathrm{S} 3\left(0\right.$ to $\left.1070 \mu \mathrm{g} \mathrm{L}^{-1}\right), \mathrm{S} 4\left(0\right.$ to $1130 \mu \mathrm{g} \mathrm{L}^{-}$ $\left.{ }^{1}\right), \mathrm{S} 5$ (0 to $170 \mu \mathrm{g} \mathrm{L}^{-1}$ ), 6 (0 to $105 \mu \mathrm{g} \mathrm{L}^{-1}, 0$ to 380 $\mu \mathrm{g} \mathrm{L}^{-1}$ ), at S8 (595 to $1620 \mu \mathrm{g} \mathrm{L}^{-1}, 1460$ to 1780 $\mu \mathrm{g} \mathrm{L}^{-1}$ ) after the religious activity (Table 3 ) and these values were found higher than the prescribed limits of water quality standards (table 4). This increase of Fe concentration may be attributed to the addition of coins and other materials made of $\mathrm{Fe}$ during the religious activity. The $\mathrm{Hg}$ concentration ranged from 0 to $111 \mu \mathrm{L} \mathrm{L}^{-1}$. The highest value was recorded at site 8 during the summer season. Bajpai et al. (2009) also reported increase in concentration of heavy metals after idol immersion in Lower Lake, Bhopal. The Ni $(20$ $\mu \mathrm{g} \mathrm{L}^{-1}$ ) was recorded at site 2 and site 8 . The $\mathrm{Pb}$, $\mathrm{Hg}, \mathrm{Cr}$ and $\mathrm{Ni}$ metals might have come through paints and colours of Diyas and small idols immersed during the religious rituals as also reported by Gupta et al. (2011). Copper is widely distributed essential metal required by all living organisms in some of enzyme systems, but at elevated concentration it acts as pollutant. The presence of $\mathrm{Cu}$ indicates pollution from anthropogenic sources due to the discharge of domestic sewage and industrial effluents that cause $\mathrm{Cu}$ pollution in receiving water. Concentrations of copper and chromium were not detected in most of the samples of surface water however, it was detected only once at S5 during the winter season and at S8 before the religious activity respectively. The concentration of $\mathrm{Cu}$ and $\mathrm{Cr}$ was found as $30 \mathrm{\mu g} \mathrm{L}^{-1}$ and $25 \mu \mathrm{g} \mathrm{L}^{-1}$ respectively. The low value of $\mathrm{Cu}$ and $\mathrm{Cr}$ indicated that there was not any significant source of copper and chromium pollution in all the study sites. Similar results were also reported by Eitei and Kh (2013). Whereas, As and Cd concentration was found to be nil at all the sites.

The heavy metals reach pond waters due to various anthropogenic activities. The main sources of these heavy metals in present studies, at sites S1 to S8 was ritual activities especially the mass bathing and other religious immersion such as the chemical colour, varnish, paints, sindur, coins and oils etc. that are added to the aquatic systems. Similar findings were also reported by Swain et al. (2005) in temple ponds of Puri Orissa and Bajpai et al. (2009) during his study on heavy metal contamination through Idol immersions in a tropical lake. Concentration of some heavy metals was found to be increased after the pilgrim dip. However, the values were recorded within the permissible limits of bathing standards (Table 4) before religious rituals.

\section{Conclusion}

The water quality indicating parameters (Table 2 and Table 3 ) at all the sites were compared with the water quality standards (Table 4 ) of bathing then it was reported that the values of $D O$ $(0.8 \pm 0.1,0.76 \pm 0.11$ at $S 6$ and $S 8$ respectively), BOD $(25.07 \pm 0.13,18.13 \pm 0.13$ at S6 and S8 respectively), COD $(131.9 \pm 2.08$ at S6), Ammonia $(2.31 \pm .23,6.57 \pm 0.02$ at $S 6$ and $S 8$ respectively) and Iron $\left(5890 \mathrm{\mu g} \mathrm{L}^{-1}\right)$ were beyond permissible limits at most of the sites and the condition was worsen at S6 and S8 might be due to higher pollution caused by large number of pilgrims and poor management practices of waters at these sites as comparison to the other sites. However, study of seasonal variation revealed that values of most of the parameters were found within the prescribed limits of bathing standard at most of the sites. The water quality assessment can play a big role in for the application of the monitoring and remediation enterprises to control pollution of waters, for drawing water quality trends thereby decreasing cost on pollution control measures and prioritizing pollution control efforts. Regular change or mixing of water after mass bathing, awareness campaigns for public regarding the suitable use of water bodies without impairing the water quality, separate bathrooms/urinals near bathing site may be the suitable remedial measures to control pollution and prevent the depletion of the quality of lentic waters. 


\section{REFERENCES}

1. Abdo, M.H. (2005). Physico-chemical characteristics of Abu Za'baal Ponds, Egypt.Egypt. J. Aquatic Res. 31(2):1-15

2. Abida, B. and Harikrishna (2008). Study on the Quality of Water in Some Streams of Cauvery River. E- J. Chem. 5(2):377-384.

3. Ahangar, I.A., Saksena, D.N., Mir, M.F. and Ahangar, M.A. (2012). Seasonal variations in physico- chemical characteristics of Ancharlake, Kashmir. Int. J. Adv. Biol. Res. 3(2):352-357.

4. Al-Badaii, F. and Shuhaimi-Othman, M. (2014). Heavy Metals and Water Quality Assessment Using Multivariate Statistical Techniques and Water Quality Index of the Semenyih River, Peninsular (Malaysia).Iranica Journal of Energy \& Environment (IJEE).5(2): 132-145.

5. Ali, M.H.H. (2002). Impact of agricultural and sewage effluents on the ecosystem of Lake Qarun, Egypt, Ph. D. Thesis, Fac. Sci., Al-Azhar Univ., Egypt.

6. Aonghusa, C.N. and Gray, N.F. (2002). Laundry detergents as a source of heavy metals in Irish domestic wastewater. J Environ Sci Health A Tox Hazard Subst Environ Eng. 37(1):1-6

7. APHA (2005).Standard Method for the examination of water and wastewater.21st Edn, APHA, AWWA, WPCF, Washington DC, USA.

8. Appavu, A. Thangavelu, S. Muthukannan, S., Jesudoss, J.S. and Pandi B. (2016). Study of water quality parameters of Cauvery River water in Erode Region. Journal of Global Biosciences. 5(9): 4556 4567.

9. Bajpai, A., Pani, S., Jain, R.K. and Mishra, S.M. (2009). Heavy metal contamination through Idol immersions in a tropical lake.Ecology Environment and Conservation.8(2): 157-159.

10.Baker, J.E., Poster, D.L., Clark, C.A., Church, T.M., Scudlark, J.R., Ondov, J.M., Dickhut, R.M. and Cutter, G. (1997).Loadings of atmospheric trace elements and organic contaminants to the Chesapeake Bay. In: Atmospheric Deposition of Contaminants to the Great Lakes and Coastal Waters, Baker, J.E. (Ed.), SETAC Press, Pensacola, pp:171-194.

11.Baptiste, A.R. and Altaff, K. (2003).Water chemistry and heavy metals in some freshwater cultural ponds of Palvakkam, Chennai, Tamilnadu, India.J. Aquat. Bio.17(1):23-25.

12.Baskar, S., Narasimhan, N., Daniel, G.S., Ravichelvan, R., Sukumaran, M. and Anandaraj, T. (2013).Seasonal Variations in physico-chemical parameters of river Cauveri, Thanjavur, Tamil Nadu, India. Int. J. Biol. Sci. 3(1):8-11.

13.Bhasin, S., Arvind, N., Shukla and Shrivastava, S. (2015). Impact of mass bathing on water quality of river Kshipra at Triveni, Ujjain, M.P., India.Int. J. Adv. Lif. 8(1):36-44.

14.Bhatnagar, A. and Sangwan, P. (2009).Impact of Mass Bathing on Water Quality.Int. J. Environ.Res. 3 (2):247-252.

15.Bhatnagar, Anita and Garg, S.K. (1998). Correlation and Multiple regression analysis of factors affecting biotic populations in river Ghaggar (India). Environ. \& Ecol. 681-685

16.Bhatnagar, Anita and Singh, G. (2010a). Assessment of Culture Fisheries in village ponds: a study in District Hisar, Haryana, India.Int. J. Environ. Res. 4
(1):57-64.

17.Bhatnagar, Anita and Singh, G. (2010b). Relations between water quality characteristics and fish yields in small scale culture ponds in Yamunanagar, Haryana. Environment \& Ecology 28(3):1615-1619.

18.Bhatnagar, Anita, Chopra, G. and Malhotra, P. (2009). Water quality indices and abiotic characteristics of western Yamuna canal in Yamunanagar, Haryana. J. Appl. Nat. Sci. 1(2):149-154

19.Biswas, B. (2000). Changing water resources study using GIS and spatial model - a case study of Bhatar Block, District Burdwan, West Bengal, India. J. Indian Soc. Remote. 37:705-717.

20.Bohra, C. (1990). Limnological survery of an ancient pond at Barwaha (Bihar). J. Freshwater Biol. 2(4):361 -364 .

21.Bubicz, M. (1982). Heavy metal in the aquatic environmental of some water bodies of the Lublin Basin. ActuaticHydrobiologia. 24:125-138.

22.Buijs, P. and Toader, C. (2007). Proposed system of surface water quality standards for Moldova, Technical Report.

23. Chandrashekar, J.S., Babu, K.L. and Somashekar, R.K. (2003). Impact of urbanization on Bellandurlake, Bangalore-a case study. J. Environ. Biol. 24(3):223227.

24.Chang, H. (2002). Spatial and temporal variations of water quality in the river and its tributaries, Seoul, Korea.Water Air Soil Poll. 161:267-284.

25.Chapman, D. and Kimstach, V. 1996. Water Quality assessments- A guide to use of biota, sediments and water in environment monitoring. Second Edition.Chapter 3. ISBN 0419215905

26.Chaturvedi, S., Kumar, D. and Singh, R.V. (2003). Study on some physico-chemical characteristics of flowing water of Ganges River at Hardwar. Res. J. Chem. Environ. 7(3):78-79.

27.CPCB (Central Pollution Control Board) (2017). Ministry of Environment, Forest and Climate Change. Government of India. Water quality Criteria. https:// cpcb.nic.in/water-quality-criteria/

28.Das, A.K. (2000). Limno-Chemistry of Some Andhra Pradesh Reservoirs.J. Inland Fish Soc.India. 32:3744

29.Dhar, G., Barat, S. and Dhar, M.K. (2004). Influence of Organophosphorus insecticide phosphamidon on lentic water. J. Environ. Biol. 25(3):359-363.

30.Dhote, S., Varughese, B. and Mishra, S.M. (2001).Impact of idol immersion on water quality of twin lakes of Bhopal. Indian J. Environ. Prot. 21 (11):998-1005.

31.Diaz, P., Guerreo, M.C., Alcorlo, P., Baltanas, A., Florin, M. and Montes, C. (1998). Anthropogenic perturbations to the trophic structure in a permanent hypersaline Shallow Lake: La Salada de Chiprana (North-Eastern Spain). Int. J. Salt Lake Res. 7:187210.

32.Duncan, D.B. (1975). t Test and Intervals for Comparison Suggested by the Data. Biometrics. 31: 339360

33.Eitei, L.S. and Kh, R. (2013).A comparative study of the ground and surface water quality with reference to heavy metal concentrations in the Imphal valley Manipur, India. Int. J. Environ. Sci. 3(6):1857

34.EPA (Environment Protection Agency). (2018). Surface water quality standards (Chapter 62) pp 1-84. https://www.epa.gov/sites/production/files/2014-12/ 
documents/fl section62-302.pdf

35.Essien-lbok, M. A.; Akpan, A. W.; Udo, M. T.; Chude, L. A.; Umoh, I. A. and Asuquo, I. E. (2010). Seasonality in the physical and chemical characteristics of MBO River, Akwalbom State, Nigeria.Nigerian J. Agriculture, Food and Environment. 6(1\&2):60-72

36.Evans, D.H. (1987). The fish gill site of action and model for toxic effects of environmental pollutants. Environmental Health Perspectives.71:47-58.

37.George, B., Nirmal Kumar, J.I. and Rita, N.K. (2012). Study on the influence of hydro-chemical parameters on phytoplankton distribution along Tapi estuarine area of gulf of Khambhat, India. Egypt. J. Aquat. Res. 38:157-170.

38.Gupta, A.K., Mishra, K., Kumar, P., Singh, C. and Srivastava, S. (2011). Impact of religious activities on the water characteristics of prominent ponds at Varanasi (U.P.), India.Plant Arch.11(1):297-300.

39.Gupta, S. and Devi, S.S. (2014).Ecology of Baskandianua, an oxbow lake of South Assam, North East India.J. Environ. Biol. 35:1101-1105.

40.Hostetti, B.B., KulKarni, A.R. and Patil, H.S. (1994).Water quality in JayanthiNallah at Panchganga at Kolhapur, India.J. Environ. Health. 36(2):124127.

41.Imnatoshi and Ahmed, S.U. (2012).Geomorphology and seasonal variations of physico chemical parameters of Doyang River, Nagaland.Int. J. Environ. Sci. 6 (1\&2):05-09.

42.Kaul, B. and Pandit, M. (2004).Morphotectonic evolution of the Delhi region in Northern India and its significance in environmental management.J. Environ. Geology. 46(8):1118-1122.

43.Khan, N., Mathur, A. and Mathur, R. (2004).A study on drinking water quality in Laskhar (Gwalior).Indian J. Env. Prot. 25(3):222-224.

44.Kulshreshtha, H. and Sharma, S. (2006). Impact of mass bathing during Ardhkumbh on water quality status of river Ganga.J. Environ. Biol. 27(2):437- 440.

45.Kulshreshtha, S.K., George, M.P. and Khan, A. (1988). Preliminary studies on the impact of certain religious activities on water quality of upper lake Bhopal. Proc. Nat. Sym. Past, present and future of Bhopal lakes: 253-257.

46.Kumada, H., Kimura, S. and Yokote, M. (1980). Accumulation and biological effects of $\mathrm{Cd}$ in Rainbow trout.Bulletin of Japanese Society of Scientific Fisheries.46:97-103.

47.Kuwabara, J.S., Topping, B.R., Moon, G.E., Husby, P., Lincoff, A., Carter, J.L. and Croteau, M.N. (2013).Mercury accumulation by lower trophic-level organisms in lentic systems within the Guadalupe River Watershed, California; (Scientific Investigations Report). USGS: Science for a changing world. pp: 2005-5037

48.Lal, A.K. (1996). Effect of Mass Bathing on water quality of PushkarSarovar.Indian J. Environ. Prot. 16 (11):831-836.

49.Mathur K., Sharma R.K., Nand K.S. and Sharma S. (1991). Water quality assessment of the river Chambal over the stretch of National Chambal sanctuary in M.P. Ind. J. of Ecol. 18(1):1-4.

50.Morales, J.A., Albornoz, A., Socorro, E. and Morillo, A. (2001). An estimation of the nitrogen and phosphorus loading by wet deposition over Lake Maracaibo, Venzuela.Water Air Soil Pollut. 128:207-221.

51.Morgan, A.M., Royer, T.V., David, M.B. and Gentry,
L.E. (2006). Relationships among nutrients, chlorophyll-a, and dissolved oxygen in agricultural streams in Illinois. J. Environ. Qual. 35:1110-1117.

52.Munawar, M. (1970).Limnological studies on freshwater ponds of Hyderabad, India. The Biotope.J. Hydrobiologia. 35:127-162.

53.National Academy of Sciences, 1972.Water Quality Criteria.Environmental Studies Board.

54.Neamtu, M., Ciumasu, I.M., Costica, N., Costica, M., Bobu, M., Nicoara, M.N., Catrinescu, C., VanSlooten, K.B. and DeAlencastro, L.F. (2009). Chemical, biological and ecotoxicological assessment of pesticides and persistent organic pollutants in the Bahlui River, Romania. Environ. Sci. Pollut. Res. Int. (1):76-85.

55.Norris, R.H., Lake, P.S. (1984). Trace metal concentrations in fish from the South Esk River, North Eastern Tasmania, Australia. Bull. Environ. Contam.Toxicol.33:348-354.

56. Osborne, L.L., Iredale, D.R., Wrona, F.J. and Davies, R.W. (1981).Effects of chlorinated sewage effluents on fish in the Sheep River, Alberta.Trans. Am. Fish. Soc. 110:536-540.

57.Pawale, R.G. (2014). Studies on scientific aspects of water quality with physico-chemical and biological factors of Vishnupuri Reservoir district, Nanded (Ms). J. Science. 4(2):93-98.

58.Rajkumar, N.S., Nongbri, B. and Patwardhan, A.M. (2003).Physico-chemical and microbial analysis of Umiam (Barapani) lake water.Indian J. Environ. Prot. 23(6):633-639.

59.Rameshbabu, K. and Selvanayagam, M. (2013).Seasonal Variations in Physico-Chemical Parameters and Heavy Metals Concentration in Water and Sediment of Kolavoi Lake, Chengalpet, India.Int. J. Chem. Tech. Research. 5(1):532-549.

60.Rangarajan, R., Sarin, M. and Swami, K. (2006).Dissolved Uranium and 234U/238U in the Yamuna and the Chambal rivers, India.J. Aquat. Geochem. 12(1):73-101.

61.Rao, D.S. and Rao, K.S. (1986). Pollution due to pilgrim's bathing during KumbhMela in Kshipra River, (Ujjain). J. Hydrobiol. 2(4):45-47.

62.Sadhuram, Y., Sarma, V.V., RamanaMurthy, T.V. and PrabhakaraRao, B. (2005).Seasonal variability of physico-chemical characteristics of the Haldia channel of Hooghly estuary, India.J. Earth Syst. Sci. 114 (1):37-49

63.Shabana, E.E. (1999). Limnological studies on Lake Bardawil, M. Sc. Thesis, Fac. Sci., Suez Canal Univ., Egypt.

64.Sharma, P. and Giri, A. (2018). Productivity evaluation of lotic and lentic water body in Himachal Pradesh, India. MOJ Eco Environ Sci. 3(5):311-317.

65.Singh, A., Ghosh, S. and Sharma, P. (2007).Water quality management of a stretch of river Yamuna.An interactive fuzzy multi objective approach. Water Res. Manag. 21(2):515-532.

66.Singh, M.R., Gupta, A., Asha, S. and Beeteswari, K.H. (2010).Physico-Chemical properties of water samples from Manipur river system, India.J. Appl. Sci. Environ. Manage. 14(4):85-89.

67.Singh, S. and Nath, S. (2015).Water quality analysis of river Ganga and Yamuna during Mass Bathing, Allahabad, India.UJERT. 5(5):251-258.

68.Singh, S., Singh, M., Bhat, M.A. and Bhawsar, A. (2016). Evaluation of water quality index of Upper Lake- ARamsar site. Arch. Appl. Sci. Res. 8(3):34-37 
69.Sinha, A.K., Pande, D.P., Srivastava, R.K., Srivastava, P., Srivastava, K.N., Kumar, A. andTripathi, A. (1991). Impact of mass bathing on the water quality of the Ganga River at Haudeshwarnath (Pratapgarh), India- a case study. J. Sci. Total Environ. 101(3):275280.

70.Snedecor, G.W. and Cohran, W.O. (1967).Statistical Method. 6th ed. The Lowa State University Press, Ames.

71.Sundararajan and Anand (2011). A study on the impact of coal washers effluents along Damodar River stretch in Dhanbad District, Jharkhand, India. IJEMS. 2(4):233-245.

72.Swain, S.K., Mohapatra, S. and Patel, R.K. (2005). A measure of pollution load in temple ponds of Puri Orissa on the basis of NSF-WQI suggestions. Polling and Research consultancy.24(3):599-603.

73.Tay, C.K., Asmah, R. and Biney, C.A. (2009). Trace Metal Levels in Water and Sediment from the Sakumo II and Muni Lagoons, Ghana. West African Journal of Applied Ecology.16:75-94.

74.Thirumala, S., Kiran, B.R. and Kantaraj, G.S. (2011).Fish diversity in relation to physico-chemical characteristics of Bhadra reservoir of Karnataka, India.Adv. Appl. Sci. Res.2(5):34-47.

75.Tyagi, S., Dobhal, R., Kimothi, P.C., Adlakha, L.K., Singh, P. and Uniyal, D.P. (2013). Studies of river water quality using river bank filtration in Uttarakhand, India. Water Qual. Expo. Health. 5(3):139-148.

76.Varunprasath, K. and Daniel, A.N. (2010).Physicochemical parameters of river Bhavani in three sta- tions, Tamilnadu, India.Iranic Journal of Energy Environment (IJEE) 1(4):321-325.

77.Vyas, A. and Bajapai, A. (2008). Water quality survey and monitoring study of idol immersion in context of lower Lake Bhopal India. In: Proceedings of Tall 2007: The 12th World Lake Conference. pp:18181823.

78.Vyas, A., Mishra, D.D., Bajpai, A., Dixit, S. and Verma, N. (2006). Environment impact of idol immersion activity lakes of Bhopal, India.Asian J. Exp. Sci.20 (2):289-296.

79.Watkar, A.M. and Barbate, M.P. (2014).Impact of idol immersion on water quality of Kolar River in Saoner, Dist. Nagpur, India.Int. Res. J. Environ. Sci., 3(3):3942

80.WHO (World Health Organisation) (1993).Guidelines of Drinking Water Quality, Vol. 1, WHO, Geneva, Switzerland, 2nd edition.

81.Winter, J.G., Eimers, C.M., Dillon, J.P., Scott, L.D., Scheider, W.A. and Willox, C.C. (2007). Phosphorus Inputs to Lake Simcoe from 1990 to 2003: Declines in Tributary Loads and Observations on Lake Water Quality. J. Great Lakes Res .33(2):381-396.

82.Wu, Y., Liu, C.Q. and Tu, C.L. (2008).Atmospheric deposition of metals in TSP of Guiyang, PR China. Bull. Environ. Contam. Toxicol. 80(5):465-468

83.Yigit, S. and Altindag, A. (2005).A taxonomical study on the zooplankton fauna of Hirfanli Dam Lake (Kirsehir) Turkey, Gazi. Egitim Fakultest Dergisi. 18:563-567. 